\title{
EDITORIAL
}

\section{Cirugía en tiempos de COVID}

\author{
Cuenca Torres, Osmar ${ }^{1}$ \\ ${ }^{1}$ Universidad Nacional de Asunción, Facultad de Ciencias Médicas, Hospital de Clínicas. San Lorenzo, Paraguay.
}

Como referenciar éste artículo | How to reference this article:

Cuenca O. Cirugía en tiempos de COVID. An. Fac. Cienc. Méd. (Asunción), 2021; 54(3): 13-16.

La pandemia por el COVID-19 se ha convertido en un problema de salud pública mundial que ha impactado con fuerza en todos los sistemas de salud, carentes en un primer momento de información para dar respuesta eficaz a una enfermedad altamente trasmisible y, con personal sanitario sin la suficiente preparación y equipamiento necesario para minimizar los riesgos de contagio (1).

En este contexto se generan nuevas problemáticas, las relacionadas con las cirugías de urgencia y cirugías impostergables, en pacientes con sospecha o confirmación de padecer esta infección y, a partir de ahí las posibles medidas a adoptar en cuanto a la seguridad de los equipos quirúrgicos y, dada la alta posibilidad de contaminación de la cirugía (2).

La priorización de cirugías de casos oncológicos ha representado una tarea difícil, debiendo sopesar los médicos un posible retraso en el diagnóstico o tratamiento del cáncer, con el riesgo de una posible exposición al COVID-19 (3).

La cirugía en tiempos de COVID ha permitido desarrollar criterios de lista de verificación de seguridad quirúrgica adaptada a pacientes con esta enfermedad con la incorporación de criterios de buenas prácticas relacionados con la infección por COVID-19 en el contexto de cirugía segura (4).

En este momento es imperioso reflexionar acerca de las medidas adoptadas en nuestra institución: ¿qué medios de actuación asumimos en cirugía para los enfermos con sospecha o confirmación de infección por COVID-19?, ¿disponemos de protocolos o normas de actuación que tengan en cuenta la seguridad de los equipos quirúrgicos en cirugía altamente contaminante por SARS-CoV-2?, entre otras reflexiones (5).

La experiencia vivida debe llevarnos a considerar la implementación rutinaria de protocolos de prácticas de cirugía segura a fin de garantizar que los equipos quirúrgicos adopten de forma sistemática medidas de seguridad que minimicen riesgos evitables que pongan en peligro a pacientes quirúrgicos $y$ profesionales sanitarios (6).

\section{Mag. Prof. Dr. Osmar Cuenca Torres Decano - Facultad de Ciencias Médicas Universidad Nacional de Asunción}

Autor correspondiente: : Mag. Prof. Dr. Osmar Cuenca Torres. Decano de la Facultad de Ciencias Médicas, Hospital de Clínicas, Universidad Nacional de Asunción. San Lorenzo, Paraguay. E-mail: cuencatorres@gmail.com

Fecha de recepción el 23 de Noviembre del 2021; aceptado el 29 de Noviembre del 2021. 


\section{REFERENCIAS BIBLIOGRAFICAS}

1. L. Zucco, N. Levy, D. Ketchandji, M. Aziz, S.K. Ramachandran. Actualización sobre las consideraciones perioperatorias del síndrome respiratorio agudo grave por COVID-19 (SARSCoV-2). Boletín informativo de la APSF, 35 (2020), pp. 35-39

2. Gobierno de España, Ministerio de Sanidad, Dirección General de Salud Pública, Calidad e Innovación, Centro de Coordinación de Alertas y Emergencias Sanitarias. Enfermedad por nuevo coronavirus, COVID-19 [actualizado 17 Abr 2020; consultado 29 Abr 2020]. Disponible en: https://www. mscbs.gob.es/profesionales/saludPublica/ccayes/ alertasActual/nCov/documentos.htm

3. P.C. Minneci, J.P. Sulkowski, K.M. Nacion, J.B. Mahida, J.N. Cooper, R.L. Moss, et al.Feasibility of a nonoperative management strategy for uncomplicated acute appendicitis in children.J Am Coll Surg., 219 (2014), pp. 272-279 http://dx.doi. org/10.1016/j.jamcollsurg.2014.02.031 | Medline

4. J.M. Balibrea, J.M. Badía, I. Rubio Pérez, E. Martín Antona, E. Álvarez Peña, S. García Botella, et al. Manejo quirúrgico de pacientes con infección por COVID-19. Recomendaciones de la Asociación Española de Cirujanos. a. Cir Esp., 98 (2020), pp. 251-259

5. Søreide K, Hallet J, Matthews JB, Schnitzbauer AA, Line PD, Lai PBS, et al. Immediate and longterm impact of the COVID-19 pandemic on delivery of surgical services. BJS; 2020. DOI: https://doi. org/10.1002/bjs.11670. [ Links ]

6. Argenziano M, Fischkoff $\mathrm{K}$, Smith $\mathrm{C}$. Surgery Scheduling in a Crisis. N Engl J Med 2020;382:e87. [ Links. 


\title{
EDITORIAL
}

\section{Surgery in times of COVID-19}

\author{
Cuenca Torres, Osmar ${ }^{1}$
}

${ }^{1}$ Universidad Nacional de Asunción, Facultad de Ciencias Médicas, Hospital de Clínicas. San Lorenzo, Paraguay.

Como referenciar éste artículo | How to reference this article:

Cuenca O. Cirugía en tiempos de COVID. An. Fac. Cienc. Méd. (Asunción), 2021; 54(3): 13-16.

The COVID-19 pandemic has become a global public health matter that has had a serious impact on health systems globally, specially to those which were deficient at the very beginning in providing information in order to offer an effective response to a highly contagious disease and with health personnel without sufficient preparation and equipment necessary to minimize the risks of contagion.

In this context, new issues have been created, particularly those linked to emergency surgeries and unpostponable surgeries, in patients with suspicion or confirmation of this infection and, from there, the possible measures to be adopted with respect to the safety of medical equipment due to the high risk of contamination during the surgery.

Prioritizing of surgeries in cancer cases has represented a hard task because the physicians must balance a possible delay in the diagnosis or treatment of cancer with a high risk of possible exposure to the COVID-19.

Surgery in times of COVID-19 has allowed the development of surgical safety checklist criteria adapted to patients with this disease by including good practice standards related to COVID-19 infection in the context of a safe surgery environment.
It is imperative currently to think on measures adopted in our institution: what actions do we assume in surgery for patients with suspected or confirmed COVID-19 infection?, do we have protocols or standards of action that consider the safety of surgical equipment in a highly contaminated surgery conditions due to SARSCoV-2?, among other considerations.

Experience should lead us to consider the routine implementation of protocols for safe surgery practices in order to ensure that surgical teams systematically adopt safety measures that minimize avoidable risks that endanger surgical patients and healthcare professionals.

\section{Mag. Prof. Dr. Osmar Cuenca Torres Decano - Facultad de Ciencias Médicas Universidad Nacional de Asunción}

Autor correspondiente: : Mag. Prof. Dr. Osmar Cuenca Torres. Decano de la Facultad de Ciencias Médicas, Hospital de Clínicas, Universidad Nacional de Asunción. San Lorenzo, Paraguay. E-mail: cuencatorres@gmail.com

Fecha de recepción el 23 de Noviembre del 2021; aceptado el 29 de Noviembre del 2021. 


\section{REFERENCIAS BIBLIOGRAFICAS}

1. L. Zucco, N. Levy, D. Ketchandji, M. Aziz, S.K. Ramachandran. Actualización sobre las consideraciones perioperatorias del síndrome respiratorio agudo grave por COVID-19 (SARSCoV-2). Boletín informativo de la APSF, 35 (2020), pp. 35-39

2. Gobierno de España, Ministerio de Sanidad, Dirección General de Salud Pública, Calidad e Innovación, Centro de Coordinación de Alertas y Emergencias Sanitarias. Enfermedad por nuevo coronavirus, COVID-19 [actualizado 17 Abr 2020; consultado 29 Abr 2020]. Disponible en: https://www. mscbs.gob.es/profesionales/saludPublica/ccayes/ alertasActual/nCov/documentos.htm

3. P.C. Minneci, J.P. Sulkowski, K.M. Nacion, J.B. Mahida, J.N. Cooper, R.L. Moss, et al.Feasibility of a nonoperative management strategy for uncomplicated acute appendicitis in children.J Am Coll Surg., 219 (2014), pp. 272-279 http://dx.doi. org/10.1016/j.jamcollsurg.2014.02.031 | Medline

4. J.M. Balibrea, J.M. Badía, I. Rubio Pérez, E. Martín Antona, E. Álvarez Peña, S. García Botella, et al. Manejo quirúrgico de pacientes con infección por COVID-19. Recomendaciones de la Asociación Española de Cirujanos. a. Cir Esp., 98 (2020), pp. 251-259

5. Søreide K, Hallet J, Matthews JB, Schnitzbauer AA, Line PD, Lai PBS, et al. Immediate and longterm impact of the COVID-19 pandemic on delivery of surgical services. BJS; 2020. DOI: https://doi. org/10.1002/bjs.11670. [ Links ]

6. Argenziano M, Fischkoff $\mathrm{K}$, Smith $\mathrm{C}$. Surgery Scheduling in a Crisis. N Engl J Med 2020;382:e87. [ Links. 